\title{
EHMTI-0355. Comparison of carbamazepine and oxcarbazepine tolerability in patients with trigeminal neuralgia
}

\author{
R Cregg ${ }^{* *}$, E Besi $^{2}$, D Boniface ${ }^{3}$, J Zakrzewska ${ }^{2}$ \\ From 4th European Headache and Migraine Trust International Congress: EHMTIC 2014 \\ Copenhagen, Denmark. 18-21 September 2014
}

\section{Introduction}

Little work has been done around the adverse events profile (AEP) of drugs used to treat trigeminal neuralgia (TN). TN patients are often unaware of significant side effects associated with pharmacotherapy.

\section{Aims}

To examine the AEP of carbamazepine and oxcarbazepine in $\mathrm{TN}$ patients.

\section{Methods}

74 TN patients averaging 1.76 outpatient consultations over 2 years and undergoing treatment only with carbamazepine or oxcarbazepine were recruited to complete the AEP questionnaire (Baker et al., 1994) at each outpatient visit in relation to the current drugs being taken for pain control. The AEP contains 19 items assessing the frequency of a range of adverse effects using a scale of 1 to 4 , with 4 indicating more frequent occurrences. Scores can range from 19 to 76 and $>45$ suggests toxicity. Drug dosages were converted to $\mathrm{mg} / \mathrm{kg}$. Efficacy of $200 \mathrm{mg}$ dose of carbamazepine is considered equivalent to $300 \mathrm{mg}$ oxcarbazepine (Beydoun 2002).

\section{Results}

Using a multilevel logistic regression model, $50 \%$ probability of significant toxicity for a $70 \mathrm{~kg}$ person is estimated at $1300 \mathrm{mg}$ carbamazepine and $2600 \mathrm{mg}$ oxcarbazepine. Women reported higher levels of toxicity. Most common side effects were tiredness, memory problems, sleepiness, difficulty in concentration, unsteadiness. Hyponatraemia occurred more frequently in patients on oxcarbazepine and is dose related.

\section{Conclusions}

At equivalent clinical doses oxcarbazepine results in fewer AEPs than carbamazepine and so should be considered as an alternative to carbamazepine in case of intolerance.

No conflict of interest.

\section{Authors' details}

${ }^{1}$ Pain medicine, University College London, London, UK. ${ }^{2}$ Facial Pain Unit, Eastman Dental Institute, London, UK. ${ }^{3}$ Health Behaviour Research Centre, Eastman Dental Institute, London, UK.

Published: 18 September 2014

\section{doi:10.1186/1129-2377-15-S1-I2}

Cite this article as: Cregg et al:: EHMTI-0355. Comparison of carbamazepine and oxcarbazepine tolerability in patients with trigeminal neuralgia. The Journal of Headache and Pain 2014 15(Suppl 1): 12.

Submit your manuscript to a SpringerOpen ${ }^{\circ}$ journal and benefit from:

- Convenient online submission

- Rigorous peer review

- Immediate publication on acceptance

- Open access: articles freely available online

- High visibility within the field

- Retaining the copyright to your article

Submit your next manuscript at $>$ springeropen.com

Pain medicine, University College London, London, UK

Full list of author information is available at the end of the article

(c) 2014 Cregg et al; licensee Springer. This is an Open Access article distributed under the terms of the Creative Commons Attribution License (http://creativecommons.org/licenses/by/2.0), which permits unrestricted use, distribution, and reproduction in any medium, provided the original work is properly cited. 